\title{
JUDICIAL REVIEW ON CONSENSUAL SOLUTIONS IN ADMINISTRATIVE MATTERS AND JUDICIAL RESPECT
}

\author{
Guilherme Calmon* \\ Estácio de Sá University, Brazil
}

Since March 2016, the Brazilian Civil Code of Procedure prescribes the execution of a mediation hearing on the disputes judicially initiated, as well as encourages conflict's consensual solutions such as conciliation and mediation, amongst others. From the work of the National Justice Board was initiated the implementation phase and the beginning of the activity of the judiciary centers of conflict's consensual resolution, ${ }^{1}$ which shall develop programs aimed to assist, orient and encourage the self-solutions. ${ }^{2}$

The Brazilian Law experiences a cultural change involving the Public Administration, especially at the federal level. The search for higher agility on the solution of disputes, the facilitation of the satisfaction of citizen's rights through small value demands (instead of public judicial certificates) and the encouragement to dispute consensual solutions - through conciliation and mediation - are aspects that show a new stage at the Brazilian judicial system on the relationships between State and the citizen.

The impact of the Judiciary management of proceedings influenced some changes on the Civil Process Code, federal law that regulates the proceeding system of rendering of judicial services on the civil sphere. The idea of access to justice has developed historically based on

\footnotetext{
* Associate Professor in Comparative Public Law in the Post-Graduate Law Program of the University Estácio de Sá / PPGD-Unesa.

${ }^{1}$ Guilherme Calmon Nogueira da Gama, Novo Código de Processo Civil e atuação do Conselho Nacional de Justiça, in 2 Reflexões sobre o nOvo Código De Processo Civil 21 (Geisa de Assis Rodrigues \& Robério Nunes dos Anjos Filho orgs. 2016).

${ }^{2}$ Código de Processo Civil, art. 165.
} 
the idea that the judicial control also impacts on administrative acts, ${ }^{3}$ as occurred with the implementation of mandatory actions (ações mandamentais), such as the writ of mandamus and the habeas corpus, besides the recently developed class actions - related to collective, general and homogeneous individual rights.

In light of the jurisdictional unity principle, the monopoly of the jurisdictional function has been assigned to the judiciary authorities, even though it is currently being questioned due to the various problems related to the effective solution of conflicts of interest. In the field of the denominated mass disputes, verified with increasing frequency, it is essential to think about the judicial proceedings that were expressly adopted on the Brazilian proceeding system, especially in relation to the notion of solutions effectiveness.

With respect to the role of the Public Administration in court, the rule is the existence of some procedural prerogatives, such as more extensive deadlines, the non-application of the rule of the formal (or false) confession, the automatic "appeal", making the proceedings against the Public Treasury slower for the effective settlement of the dispute, in addition to causing greater costs to the citizens. The dogma of the unavailability of the public interest involving conflicts with the Public Administration is currently being questioned. ${ }^{4}$

The Law no. 13.140/15 expressly initiated to contemplate the possibility for the Public Treasury to act on matters of consensual solution of conflicts with its administrated citizens. In fact, it is being a long time that extrajudicial solutions of issues involving the Government and the citizen are accepted, as in the examples of the friendly expropriation (Decree-Law n. 3.365/41) and the term of adjustment of conduct. With the Mediation Act and the new Code of Civil Procedure, there was stimulus to the search for the consensual solution, including in litigation involving the Public Administration. ${ }^{5}$

Another point that deserves attention is the need for technical and scientific qualification of certain people - as in the case of amicus curiae - to be admitted into judicial

\footnotetext{
${ }^{3}$ J. Guilherme de Aragão, A justiça administrativa no Brasil, CADERnOS DE ADMINISTRAÇÃo PúBLICA- FGV EBAP 24 (1955).

4 Marcella Araújo da Nova Brandão, A CONSEnsualidade e a ADMinistraÇÃo PÚbliCa em JUÍzo 54 (Dissertação de Mestrado Escola de Direito da Fundação Getúlio Vargas 2009).

${ }^{5} I d .$. at 63 .
} 
and administrative procedures, in order to make it possible to understand the various aspects of the interests under discussion. ${ }^{6}$

In the context of the Brazilian Labor Justice, there was already the provision of the possibility of the extrajudicial conciliation to solve certain conflicts, including the use of the Union organizations for the conclusion of collective labor conventions or agreements, in the today's common idea of the correct breadth of access to justice. The long-term solution, full of formalities from judicial proceeding, can be translated into an injustice in certain events and, therefore, the constitutional amendment n. 45/2004 inserted the guarantee of the reasonable duration of the proceeding so that no more judicial demands - and, why not administrative procedures - which were eternal.

Access to justice, based on the informality of the effective solution of the conflict, through the cooperation of the subjects involved, points to the need to pay attention to the really relevant issues that are taken to the judiciary system. And, under such highlight, the contemporary judge needs to be aware of the importance of leading the parties to the friendly composition in a quick and effective manner. The procedural system should be reinterpreted under the focus of informalism in conflict resolution, through institutionalized cooperation, in the constant search for construction and effective access to justice in an expanded manner. In the United States of America, the widening of access has been made through the creation and development of Alternative dispute resolutions (ADRS), which have encompassed programs to focus on the use of extrajudicial means to solve conflicts, such such as mediation, negotiation and arbitration.

Such ideas cannot exclude issues involving the Public Administration and those administered by it, in particular in a Democratic State, in which fundamental rights gain significant importance also in the relations considered of Public Law. The use of the tools for consensus-solving methods of conflict does not represent the failure of judicial protection. On the contrary: it reinforces the role of the Justice System through a solution awarded to conflicts in cases where the consensual solution is not really possible.

\footnotetext{
${ }^{6}$ MAURo CAPPELLETTI \& BRyANT GARTH, ACESSO À JUSTIÇA 68 (1998).
} 
It is no longer possible to maintain the idea of the perpetuation of jurisdiction in the state view as the only way to solve conflicts; on the contrary, it is important to deep in the vision concerning the solving of conflicts thorough informalism and cooperation, including with the presence of the Public Administration. There must, of course, preserve the observance of the constitutional principle of independence and harmony between the state powers, and it is certain that in exceptional situations - and duly restricted - it will be possible to exercise judicial control over the friendly compositions encompassing as one of the subject the Public Treasury. Jurisdiction is an activity monopolized by the State, but it does not monopolize the solving of conflicts.

The work to be developed points out to a new model of resolution of conflicts of interest in contemporary society, identifying appropriate and effective means to confirm the constitutional principles in order to achieve effective access to justice, even with regard to issues involving Public Administration.

\section{REFERENCE LIST}

G. C. N. da Gama, Novo Código de Processo Civil e atuação do Conselho Nacional de Justiça, in 2 REFleXõEs SOBRE O NOVO CóDIGO DE PROCESSO CIVIL 21-58 (Geisa de Assis Rodrigues \& Robério Nunes dos Anjos Filho orgs. 2016).

J. G. de Aragão, A justiça administrativa no Brasil, CADERnOS DE ADMINISTRAÇão PÚBLICAFGV EBAP 1-46 (1955).

M. A. DA Nova BRANDÃo, A CONSENSUALIDAdE E a ADMINISTRAÇÃo PÚBLICA EM JUÍzo (Dissertação de Mestrado, Escola de Direito da Fundação Getúlio Vargas 2009).

M. CAPPElletTi \& B. GaRTh, ACESSO À JUSTIÇA (1998).

Submetido em: 17/07/2019

Aceito em: 05/08/2019 